\title{
NARRADORES E NARRATIVAS DO CARNAVAL DE RUA CARIOCA
}

Jorge Sapia (IBMR); Andréa Estevão (Unesa)

Os blocos de carnaval de rua cariocas fazem de forma perspicaz e irreverente a crônica dos acontecimentos que marcaram a história do Rio de Janeiro, do país e até mesmo do mundo, através de seus sambas, narrativas cantadas, em que o riso, o humor, o deboche contra o poder, os poderosos e os mecanismos disciplinadores típicos dos processos modernizadores são questionados e criticados. Essas narrativas resultam muitas vezes de competências de recepção que, não podendo resistir aos processos de agendamento, subvertem e transfiguram o discurso oficial e midiático.

NARRATIVA; CARNAVAL DE RUA; RIO DE JANEIRO; SAMBA.

SAPIA, Jorge; ESTEVÃO, Andréa. Narradores e narrativas do carnaval de rua carioca. Textos escolhidos de cultura e arte populares, Rio de Janeiro, v.11, n.2, p. 47-66, nov. 2014. 


\section{STORYTELLERS AND NARRATIVE OF CARIOCA STREET CARNIVAL}

Jorge Sapia (IBMR); Andréa Estevão (Unesa)

The Rio carnival street blocks are an insightful and irreverent way to chronicle the events that have marked the history of Rio de Janeiro, the country and even the world, through their sambas - sung narratives - in which laughter, humor, the mockery against power and the powerful and the disciplining mechanisms typical of modernizing processes are questioned and criticized. These narratives are often a result of reception capabilities that cannot resist the process of forced associations, therefore subverting and transfiguring the official and the media discourse.

NARRATIVE, STREET CARNAVAL, SAMBA, RIO DE JANEIRO

SAPIA, Jorge; ESTEVÃO, Andréa. Narradores e narrativas do carnaval de rua carioca. Textos escolhidos de cultura e arte populares, Rio de Janeiro, v.11, n.2, p.47-66, nov. 2014. 
A população da cidade do Rio de Janeiro tem paixão pelas ruas. É na rua que mostra sua inclinação para a alegria tanto quanto sua insatisfação. A ligação do carioca com o carnaval não é estereótipo, mas traço marcante da identidade. É no carnaval ou de forma carnavalesca que ele se expressa, declara seu amor à cidade, sua indignação, narra as vicissitudes de sua história cotidiana. Tanto no início do século XX quanto na década de 1980 e ainda hoje, as músicas compostas para o carnaval, principalmente as marchinhas e os sambas de bloco de rua, apresentam visão peculiar da história, dos comportamentos, dos fatos marcantes do dia a dia do cidadão em sua cidade, em seu país. Do diverso e polifônico carnaval carioca nos interessa neste artigo apresentar algumas particularidades das canções-narrativas dos blocos que surgiram no Rio de Janeiro na década de 1980, contexto da transição democrática. Esses sambas apresentam olhares e sustentam perspectivas bem-humoradas e críticas, mas principalmente divergentes da história oficial ou da versão homogeneizadora da grande mídia, e é justamente sobre esse aspecto que queremos tecer considerações iniciais. ${ }^{1}$

\section{QUEM DESCOBRIU O BRASIL? FOI SEU CABRAL...}

No Carnaval de 1934, no Rio de Janeiro, caiu no gosto popular uma marchinha cujo título é "História do Brasil". Seu compositor, Lamartine Babo, foi um dos responsáveis pela invenção da tradição das marchinhas que animam, ainda hoje, os festejos carnavalescos. Os compositores desse gênero musical tiveram sua época de ouro no contexto do desenvolvimento de uma cultura popular de massa cujo veículo principal era o rádio organizado comercialmente (ORTIZ, 1989). Oriundos da classe média urbana produzem uma identidade "constituída basicamente a partir do estranhamento dos padrões associados ao universo pequeno-burguês" destilando "o veneno da irreverência" em versos que carregam o espírito humorístico e alegre do modernismo (NAVES, 1998, p. 97 e 116). Pensando a relação entre modernismo e música popular, Santuza Cambraia Naves (1998, p. 77) observa o desenvolvimento de uma estética da simplicidade e da fragmentação em oposição à experiência totalizante da arte monumental. Esse espírito da simplicidade está presente tanto nos representantes do movimento modernista quanto nos compositores da música popular que contribuem para tornar hegemônicos o samba e a marcha na década de 1930.

Figura central do movimento modernista, Oswald de Andrade defende no Manifesto da Poesia Pau-Brasil, publicado em 1924, a ideia de que modernizar a arte brasileira passa por assentá-la nas tradições nacionais populares. A ideia é superar o que denominou passadismo, ou seja, desvincular-se das tradições ba- 
charelescas herdadas do Império. O que Oswald de Andrade propõe, contra a erudição e a cópia, é a redescoberta do Brasil "pela invenção e pela surpresa".

Invenção e surpresa são dois aspectos presentes no carnaval e podem ser encontrados em diferente cenários: nas fantasias individuais e coletivas que os foliões inventam; nas mensagens visuais dos carros alegóricos e comissões de frente nas escolas de samba; nas letras, melodias e performances que animam os blocos de rua.

Nota-se nos compositores destas últimas agremiações traços do que Monica Velloso (1996) no livro Modernismo no Rio de Janeiro identifica como Turunas e Quixotes: ${ }^{2}$ a preocupação com o "registro da cidade e do país através das suas ruas". A autora discute o papel de um grupo particular de intelectuais no Rio de Janeiro no início do século XX: os humoristas boêmios que irão colocar "no debate político-intelectual a questão do humor associada diretamente à problemática nacional" (p. 14). Reconhecidos como situados à margem da ordem social, Turunas e Quixotes se impõem socialmente por seu caráter de outsiders.

É importante considerar a dimensão de outsiders, pois ela está presente nos grupos que, nos anos 80 , no final do Estado autoritário, ingressaram na cena do carnaval carioca, transformando-a. A ocupação das ruas como manifestação carnavalesca se dá num contexto que privilegiava o desfile das grandes escolas de samba e as festas realizadas em clubes fechados. Essa modalidade registra hoje densidade não desprezível. Os números, ainda pouco sistematizados, da nova economia do carnaval e do espaço que o carnaval de rua tem hoje nas diversas mídias sugerem um deslocamento da experiência da festa nas ruas, das margens para o centro da cena carnavalesca. A nova realidade ocupa lugar relevante tanto nos corações e mentes da juventude quanto nas políticas públicas, que precisam considerar o impacto das mudanças registradas e propor mecanismos de gestão adequados para os novos formatos que a festa assume no espaço urbano. ${ }^{3}$

Hoje é possível imaginar a existência de um ponto de interseção entre os foliões e as muitas multidões que ocupam as ruas do mundo pós-fordista reivindicando, como postula Milton Santos (2004), outra globalização. No Brasil e particularmente no Rio de Janeiro, os modos de participação nos movimentos que deram origem às Jornadas de Junho ${ }^{4}$ sugerem um processo de carnavalização da mobilização política. Processo que apresenta, simultaneamente, os elementos acima destacados: invenção, surpresa e descobrimento.

As manifestações que se disseminaram na cidade e no país, a partir de junho de 2013, podem ser lidas, também, como experiência carnavalesca. Nesse sentido, vinculam-se à perspectiva aberta por Bakhtin (1987, p.10), para quem as formas e os símbolos da "linguagem carnavalesca estão impregnados do liris- 
mo da alternância e da renovação, da consciência da alegre relatividade das verdades e autoridades no poder". Barbara Szaniecki, ${ }^{5}$ ao comentar as Jornadas de Junho, enfatiza a dimensão carnavalesca nelas presente, "que subverte os poderes opressores e se desdobra em obras polifônicas". Na mesma perspectiva, Ivana Bentes ${ }^{6}$ argumenta que vivemos

um momento decisivo em que demandas singulares e plurais se encontram num impulso de mobilização e ação. Em termos estéticos o que vi nas ruas foi uma espécie de carnaval político com blocos de manifestantes em torno de causas, geralmente de grupos mais organizados e corporativos, movimentos que já estavam aí.

Encontramos fora do espaço-tempo do carnaval a descoberta da carga simbólica da fantasia, no duplo sentido que o termo possuí na língua brasileira: "tanto se refere às ilusões e idealizações da realidade quanto aos costumes usados somente no carnaval" (DAMATTA, 1981, p. 48).

\section{EU QUERO É BOTAR MEU BLOCO NA RUA}

Os blocos carnavalescos foram precursores das escolas de samba e constituem uma das tantas formas de expressão do carnaval. Em rápida pincelada histórica podemos mencionar a experiência dos cucumbis, do zé-pereira, do entrudo, das grandes sociedades, dos ranchos, cordões, blocos e, finalmente, das escolas de samba.

Uma definição canônica de blocos os caracteriza pela indumentária uniforme de seus participantes, pelo entoar de um hino-marcha ou samba composto especialmente para animar o cortejo, por um conjunto de percussão e, geralmente, um estandarte (CASCUDO, 1962, p. 115 e 240, apud QUEIROZ, 1994).

Para DaMatta (1981, p. 98), bloco dá ideia de algo compacto e sólido, "poderoso, grande, avassalador, mas sem a necessária ordenação interna para representar e (elaborar) um drama capaz de promover impacto duradouro ou expressar nitidamente um certo ponto de vista com suas necessárias nuanças". As transformações ocorridas nas festas públicas na virada do século XXI, no entanto, nos levam a relativizar essa ideia e considerar outras possibilidades. Além dos blocos tradicionais orientados pela lógica do concurso, da competição e do julgamento, discutidos, entre outros, por Da Matta (1981), Ferreira (2005) e Queiroz (1994), nos interessa considerar a experiência de uma cidade compartilhada por um quantitativo de quase 500 agremiações que se espalham pela malha urbana. Dados apresentados pela Prefeitura em 2013, por intermédio da Empresa de Turismo do Município do Rio de Janeiro S.A. (Riotur), informam a participação de 5.300.000 foliões nos blocos, gerando renda estimada em 848 milhões de dóla- 
res. Esse crescimento e seus impactos são discutidos por Bruno Cavalcanti (2013, p.10) em artigo sobre os novos formatos das festas nas últimas décadas: "várias dessas festas públicas brasileiras assumiram grandes proporções demográficas, econômicas e midiáticas, apontando para uma característica pós-industrial dessa economia simbólica de serviços ligados à curtição coletiva da vida, especialmente em entretenimentos festivos de massa."

Embora existam gradações, a nova forma processional do encontro aberto incorpora cada vez mais foliões como atores e não necessariamente como espectadores. ${ }^{7}$ A lógica da participação deixa-se perceber na presença a cada ano mais intensa de pessoas fantasiadas na folia da cidade. As fantasias, lembra DaMatta (1981, p. 49), criam "um campo social de encontro, de mediação e de polissemia social, pois, não obstante as diferenças e incompatibilidades desses papéis representados graficamente pelas vestes, todos estão aqui para brincar". Essa forma de ir para as ruas fantasiado estendeu-se para além do espaço-tempo do carnaval nas manifestações de junho e hoje é fruto de longa e controvertida polêmica a respeito do direito de utilizar máscaras nas ruas fora do período carnavalesco. ${ }^{8}$

A classificação de bloco, no Rio de Janeiro é hoje bastante elástica. São assim denominadas todas as novas experiências de encontros musicais e afetivos nas ruas da cidade. Na clássica interpretação do dilema brasileiro, Da Matta argumenta ser a festa ritual essencialmente noturno, por oposição à parada militar no Dia da Pátria, ritual diurno. A configuração mudou. O carnaval de rua é realizado a cada ano mais cedo. Há clara preferência do folião em frequentar blocos que começam seu desfile com o apito da fábrica de tecidos que tanto incomodou Noel Rosa na música "Três apitos". ${ }^{9}$

Podemos, não obstante, estabelecer uma distinção sumária dos tipos de bloco hoje existentes. Há blocos musicais, como o Céu na Terra, o Cordão do Boitatá e o bloco Virtual, que utilizam preferencialmente instrumentos de sopro, convidando os participantes - quase todos fantasiados - a cantar em coro sambas e marchinhas tradicionais; há blocos de gênero, como o Mulheres de Chico, que cantam o repertório de Chico Buarque de Holanda em ritmo carnavalesco, ou o Mulheres de Zeca; ${ }^{10}$ há blocos temáticos, como Toca Raul, Fogo e Paixão, Exalta Rei, que desenvolvem repertório de ícones da cultura de massa, como Raul Seixas, Wando e Roberto Carlos; além de blocos que dialogam com diferentes tradições musicais produzindo as mais diversas fusões. Há os que transitam tanto no universo do rock, Bloco Cru, quanto do funk, os que dialogam com a música caribenha ou aqueles que resgatam as tradições populares do maracatu rural. ${ }^{11}$ Existem hoje ícones da cultura pop global, como os Beatles, que foram traduzidos em batida percussiva pelo recentemente criado bloco Sargento Pimenta. No Rio e Ja- 
neiro basicamente - e diferentemente de outras realidades, como o carnaval da Bahia - e a despeito dessa pujante diversidade, os blocos são abertos à participação de todos, sem cordas e sem obrigatoriedade de indumentária própria.

Consideramos ainda oportuno acrescentar a caracterização que Moacyr Luz, compositor, escritor e fundador do bloco Nem Muda, Nem Sai de Cima fez do bloco carnavalesco. Tal caracterização dialoga com a ideia de invenção da tradição, trabalhada por Hobsbawn (2004):

O bloco nasce na birosca, na pelada de casado e solteiro, no churrasco na laje, na ilusão necessária para ser feliz. Um gaiato, sempre bem-humorado dá nome ao filho, o intelectual define as cores a partir de uma conclusão histórica e, uma semana depois começam os 'finalmentes'. Depois vêm os sambas. Poetas da cidade, criamos refrões e ironias, hologramas de Lamartines e Braguinhas, cadenciados feito Zé Kéti, João Roberto Kelly. Chegam os vizinhos. Vêm como quem corre no Cosme e Damião. Formam-se alas, amigos distantes, vaquinha pra cerveja da bateria ainda improvisada, e o coração apertado no dia do desfile. O bairro toma partido, livro de ouro e um pequeno trecho de via interditado. Com a data oficial da apresentação decretada, está criada a nova tradição do carnaval. ${ }^{12}$

Além dessa sumária apresentação, nos interessa observar aqueles blocos que desfilam em forma de cortejo, com um conjunto percussivo e com sambas autorais feitos especificamente para a ocasião. Isso nos fala da existência de um campo de criação da qual participam, em interessante fertilização cultural, músicos tanto profissionais quanto amadores - compositores com trânsito no mercado fonográfico e muitos que aprenderam o ofício na pressão da folia e que, nem sempre, se aventuram a ingressar em domínios mais profissionais, mantendo o processo criativo na esfera da sazonalidade. Tampouco se identificam como sambistas, categoria importante no universo das escolas de samba (CAVALCANTI, 2006).

São compositores de blocos, produzem nesse momento particular, premidos pelo tempo que corre de forma inexorável e a dilatação, por parte dos responsáveis pelas agremiações, dos prazos para marcar as escolhas dos sambas que serão cantados durante o cortejo. Não é incomum escolher a obra num dia e desfilar dois dias depois. É tempo suficiente para imprimir a letra do samba e distribuí-la aos foliões, que tomam, então, conhecimento da letra, da melodia e do tema focado. Há, portanto, também nesse momento, um sentido de surpresa e descoberta.

Essa nova tradição se inicia na década de 1980, no contexto da transição democrática, com a criação do bloco carnavalesco Clube do Samba, projeto de 
resistência do compositor João Nogueira. Esse, assim como os blocos de embalo tradicionais Boêmios de Irajá, Bafo da Onça e o Cacique de Ramos inspiraram os blocos que fazem parte do que denominamos retomada carnavalesca, isto é, a invenção de uma série de experiências organizadas na Zona Sul da cidade, por grupos sociais das camadas médias, vinculados à luta contra o regime autoritário e a diversos movimentos sociais. Estevão e Sapia (2013, p. 132) registram que esses blocos surgiram no vácuo da derrota das Diretas Já, por atores que "recusam a desmobilização e abrem a possibilidade de contar outra história, que inclui a informalidade da brincadeira de rua, do riso, da ironia, da crítica social e de costumes, elementos presentes nos sambas que animam os cortejos". Esse movimento se orientou no sentido da ocupação da rua, do espaço público, transformando, nos últimos anos, as representações que o carioca tinha e tem sobre sua cidade.

Os compositores que militam nas escolas de samba, movimentam-se num universo cujos contornos estão demarcados pelo enredo e detalhados na "sinopse do enredo" elaborada pelo carnavalesco da escola e apresentada, de maneira pedagógica, em diversos encontros semanais.

O enredo é aquele elemento por meio do qual a forma estética padronizada do desfile se abre ao contexto histórico e cultural, pois a renovação anual de seu tema assegura-lhe a atualidade e a diversidade. Orientando o espetáculo, os enredos promovem a cada ano imensas conversas urbanas sobre os mais diferentes assuntos. Assim, garantem a continuidade e a renovação do desfile, tornando-o um referencial para a constante construção, reiteração e alteração de identidades (carioca, brasileiro, salgueirense, mangueirense, carnavalesco, anticarnavalesco, etc.) (...) esse ritual, ao mesmo tempo padronizado e flexível, tem sua própria história, e é preciso compreendê-lo em sua relação com a vida da cidade (CAVALCANTI, 1999, p. 82).

A apresentação do enredo aos compositores constitui um momento crítico no ciclo dos desfiles (CAVALCANTI, 2006, p. 111). O detalhamento e a explicitação daquilo que deve ou não entrar no samba estabelece uma espécie de coautoria entre carnavalesco e compositores. Uma vez que "Um samba-enredo elabora ideias e palavras dispostas por outrem, retirando da prática do 'fazer poesia' um dos seus prazeres", é comum que os compositores não se sintam muito à vontade com esse tipo de cerceamento (p. 118).

Diferentemente dos compositores mencionados, em geral reconhecidos a partir de sua identidade como sambistas, ${ }^{13}$ os compositores dos blocos de rua trabalham num universo de menor controle de sua produção, o que permite maior liberdade para tratar de temas da agenda política e de costumes sem o cercea- 
mento referido. No caso que nos interessa pensar, os rituais e as escolhas temáticas assumem formas diferentes. Por regra geral se observa a produção de crônicas bem-humoradas, críticas ácidas, e releituras irreverentes da história recente no Rio de Janeiro, do Brasil e do mundo, num processo dialógico com as manchetes de jornal.

As narrativas produzidas no samba, elaborado muitas vezes por parcerias construídas em função da disponibilidade de tempo, têm mais autonomia e espontaneidade. Feitos "no calor dos acontecimentos" esses sambas têm, geralmente, o registro da urgência. Essa peculiaridade é bastante acentuada em algumas agremiações. No bloco carnavalesco Imprensa Que Eu Gamo, criado por jornalistas que participavam da Caminhada pela Paz, organizada em 1995 pelo Movimento Reage Rio e por Betinho, o Herbert de Souza, irmão de Henfil, não foram poucas as vezes em que o samba vencedor incorporou, na letra, as manchetes dos jornais do dia da disputa. Muitas vezes era a frase que os compositores esperavam para, na sua linguagem, "arredondar" o samba que estava quase pronto. Aqui também, portanto, e parafraseando Cavalcanti (2006, p. 104), "pode-se perder ou ganhar um carnaval aí". A composição é, muitas vezes, finalizada poucas horas antes da apresentação, e o elemento surpresa desempenha importante papel.

\section{DESCOBERTAS}

Iniciamos este artigo com uma referência à música "História do Brasil", de Lamartine Babo, que embalou os foliões no Carnaval de 1934:

Quem foi que inventou o Brasil? / Foi seu Cabral. Foi seu Cabral / No dia vinte e um de abril / Dois meses depois do carnaval.

Lamartine ressignifica "A carta do achamento do Brasil" escrita por Pero Vaz de Caminha em abril de 1500. Reafirma, em seus versos, um dos mitos fundadores da cultura brasileira, a invenção do Brasil por Portugal, e registra a centralidade da festa carnavalesca transformada em símbolo da identidade nacional na década em que a marchinha foi criada. Desde então, como festa instituída pelo Estado nacional, o carnaval estará sujeito tanto a incentivos quanto a controles do poder público (ALBUQUERQUE JUNIOR, 2011). Esse duplo movimento está manifesto no estatuto de fundação da União das Escolas de Samba (UES) em 1934. Como mostram Lima e Fillipo (2012), o estatuto elaborado pelos representantes das escolas de samba privilegiava enredos que exaltassem a grandeza e o futuro promissor da sociedade brasileira. A participação dos integrantes das escolas na elaboração das normas e regras que orientam a leitura dos compositores relativi- 
za a ideia, presente em diversos autores, de que tal medida tivesse resultado unicamente da imposição do Estado. Os autores comentam:

a estética das agremiações carnavalescas surgidas no século XX não pode sustentar a tradição de jocosidade, sarcasmo e crítica política: às escolas de samba da década de 1930 dificilmente seria permitida tamanha liberdade de expressão. Como dependiam do reconhecimento do Estado, da imprensa e da sociedade, não lhes convinha adotar postura abertamente crítica: nada de reivindicações, de enredos sobre conscientização de problemas sociais ou de denúncias à conjuntura social, enfim, nada que pudesse subverter a ordem. Desse atrelamento político surgiu a necessidade das escolas de louvar com seu samba e sua arte a história oficial do país, suas riquezas, sua natureza, seus heróis, seu povo digno e trabalhador (LIMA, FILLIPO, 2012, p. 127).

Atualmente, é o mercado que orienta boa parte dos enredos que as escolas de samba apresentam no popular sambódromo. De estados da federação a marcas de produtos (cavalo Manga Larga Marchador, iogurte Danone) financiam o desfile de escolas em troca da visibilidade e exaltação de suas marcas.

O mercado descobriu a festa de rua e desenvolveu diversas estratégias de marketing que geram uma arena carregada de conflitos. Paulo Migues (1996, p.15) discute a relação entre festa e mercado no carnaval da Bahia e afirma que "a compreensão do carnaval como um fenômeno que se realiza em rede supera a tentação, no mínimo saudosista, de imaginar a festa realizando-se independente do negócio, como se possível fosse negar o caráter de mercadoria que os espaços, todos eles, adquirem no capitalismo".

Embora o carnaval que ganha projeção global ainda seja o dos desfiles das escolas de samba da Marquês de Sapucaí, o cenário carnavalesco carioca é múltiplo, polifônico. A sutileza e o humor constituem uma constante nos sambas que animam esses blocos. Recorremos novamente a Velloso (1996, p. 61) para reafirmar, com ela, que o humor é polissêmico, "ele é capaz de incluir a ideia de combate, passatempo, denúncia, diversão, irreverência e informação".

O samba vencedor do Carnaval de 1991 do Bloco de Segunda nos permite exemplificar o comentário anterior. Foi o ano que marcou o início da Era Collor, personagem da política nacional que articulou sua campanha em torno da necessidade de colocar o país no rumo da modernidade, associada a valores como progresso e civilização. Collor recupera a tradição de pensar a modernidade como projeto (ORTIZ, 1989), como algo a ser conquistado no futuro que passa, na proposta do então candidato, pela implementação de políticas orientadas pelo ideário neoliberal: Estado mínimo, privatizações, modelo de acumulação fle- 
xível, incertezas e insegurança que contribuem com o desenho de um cenário orientado pela corrosão do caráter (SENNETT, 2000). Época, também, do confisco da poupança ordenado pela ministra da Economia, Zélia Cardoso de Mello, e pelo presidente do Banco Central, Ibrahim Eris (conhecido popularmente como o Turco Eris). Turco, no Brasil, é a designação genérica de imigrantes do Oriente, em particular sírios e libaneses. Foi também o ano da Guerra do Golfo (1991), da invasão do Kuwait pelas tropas iraquianas de Saddam Hussein; da utilização do míssil balístico Scud, de origem soviética. Parece inusitado, mas o enredo estava dado. $\mathrm{O}$ samba ganhador consegue dar conta desse conjunto de informações fragmentadas que a mídia reproduzia e o faz com absoluta naturalidade:

A um passo da Modernidade / Ultrapassado nós tratamos com desdém / Coisa mais antiga que Riad / Só o turco Eris, o Sírio de Belém / O bloco de Segunda qualidade / Canta o futuro, acredita e diz amém / Se os jovens aliados só dão uma / Sem muito esforço Saddam dá mais de cem / O Scud quem minha senhora / Esses Scuds são de quem? / Dos patriotas que alumiam as noites de Jerusalém.

A imagem de Fernando Collor, o "caçador de marajás", olhando com desdém os símbolos do atraso -: o Estado aumentado, as carroças da indústria nacional, entre outros -, está implícita nos primeiros versos. O segundo verso faz referência ao "jovem" representante do Banco Central como "coisa mais antiga que Riad"; faz um sutil trocadilho entre sírio (turco) e círio de Belém (tradicional procissão católica de cidade de Belém do Pará). Finalmente, arremata numa frase, cantada com um sorriso cúmplice que custou abandonar a boca dos foliões, a pergunta sobre os responsáveis da tecnologia da destruição utilizada na guerra, os mísseis Scud, fazendo trocadilho pela semelhança fonética, com a parte da anatomia humana culturalmente valorizada entre nós. Finalmente, responde, tomando partido a favor de Saddam Husseim, líder "dos patriotas que alumiam as noites de Jerusalém". Capacidade de síntese digna de nota.

As narrativas produzidas nos sambas dialogam com a pluralidade cultural presente numa "cidade porosa, uma cidade onde as influências culturais desestabilizam fronteiras, onde há uma hibridação contínua fertilizando trocas culturais e, imaginários simbólicos e sonhos de vida" (JAGUARIBE, 2007, p. 11414). As cidades, segundo destaca a autora, são produto da imaginação e de vivências subjetivas e coletivas que disputam tanto o presente quanto o passado que "se renova nas práticas do cotidiano, nas crenças, nos rituais, nas tradições e nos sonhos coletivos.(...) por grupos, instituições, empreendimentos e pessoas". Da mesma forma, embora as cidades continuem a ser desiguais e desagregadoras, são produzidas diversas narrativas "que ora colocam em evidência a desorientação dos su- 
jeitos e do sentido do lugar, ora celebram seu potencial democrático e emancipatório" e podem ser vistas nos programas de ocupação e compartilhamento dos espaços públicos de copresença nas cidades que a experiência carnavalesca revitaliza. No mundo brasileiro, observa DaMatta (1981), não são somente as praças que produzem comunicação e encontros. As instituições da praça têm também esse papel. É precisamente isso o que fazem, para o autor, os grupos de carnaval. Comunicação, encontros e invenção são elementos que de alguma forma produzem "a própria reinvenção da cidade e a regeneração da cultura urbana" (FORTUNA, SILVA, 2011, p. 432 e 455). Estamos, nos parece, em presença de um processo de ocupação do espaço público pela festa.

Nesse modelo de festa a perspectiva crítica e a sátira política ocupam lugar privilegiado. $O$ poder, os poderosos e os mecanismos disciplinadores típicos dos processos de modernização são questionados e criticados na língua afiada do humor e do deboche. Humor também é reflexão, pondera Monica Pimenta Velloso $(2000$, p. 21$)$ :

humor é coisa séria. Pode-se perfeitamente ter uma atitude de seriedade sem ser necessariamente sisudo ou carrancudo. É rindo que entendemos muitos aspectos de nossa vida e da realidade histórica. O riso pode provocar indagações e dúvidas. E é justamente a partir dessas indagações que começamos a refletir e a procurar saídas.

Essas narrativas são, muitas vezes, resultados de competências de recepção que, não podendo resistir aos processos de agendamento, subvertem, transfiguram o discurso. Em regra, os sambas produzidos a cada ano costumam assumir duas posturas, que podem vir mescladas: a crônica da cidade e/ou uma leitura contra-hegemônica da história oficial e do agendamento empreendido pela produção jornalística das grandes empresas de comunicação sobre os mais diversos assuntos, sejam eles locais ou globais. Aqui nos interessa particularmente explicitar as nuanças da discussão sobre o direito à cidade, que essa festa de rua hoje evoca.

\section{OUTRAS DESCOBERTAS}

Passados 80 anos do lançamento da marchinha do Lamartine, e dois meses do Carnaval de 2013, foi descoberto na mesma cidade outro seu Cabral. Trata-se do governador do Estado do Rio de Janeiro, eleito para seu segundo mandato, em 2010 e gozando, até sua redescoberta, de boa saúde política, embora existam registros de compositores que produziram versos e rimas críticos em sua intenção e direção. Foi nessa época que o seu Cabral - governador - amparado em 
decisão judicial, mandou desocupar as instalações do antigo Museu do Índio, conhecido hoje como Aldeia Maracanã. O prédio, construído em 1862, é um casarão em ruínas ocupado, desde 2006, por vários coletivos e diversas etnias que defendiam a construção, no local, de um grande centro cultural. O governo do estado, entretanto, orientou suas políticas públicas na cidade pelas determinações da Fifa, e a ocupação da Aldeia Maracanã interrompia o calendário de obras da Copa do Mundo. O local seria destinado a outro projeto: a construção de um estacionamento próximo ao novo estádio. O governador confirma em entrevista que "O Museu do Índio, perto do Maracanã, será demolido. Vai virar uma área de mobilidade e de circulação de pessoas. É uma exigência da Fifa e do Comitê Organizador local. Viva a democracia, mas o prédio não tem qualquer valor histórico, não é tombado por ninguém. Vamos derrubar".15

O anúncio da demolição foi o estopim para o primeiro conflito em um ano fértil de confrontos nas ruas da cidade entre o poder público e diversos segmentos da sociedade civil que conquistaram a partir de então espaço público e publicidade. Esses acontecimentos se repetirão como pauta no carnaval que ocupará as ruas em 2014. Para surpresa geral, os jovens voltaram às ruas fora do período carnavalesco com alegria, disposição e criatividade. E, como palavra de ordem, ressignificaram a propaganda oficial, exigindo padrão Fifa na saúde, na educação, na segurança, na mobilidade urbana. Enfim, como resumia um dos milhares de cartazes desfraldados nesse tsunami cívico: “É muito motivo! Não cabe aqui!”

Antecipando o que estaria por vir, essas preocupações estavam presentes nos enredos defendidos por alguns blocos carnavalescos da cidade. É o caso do Meu Bem, Volto Já, que comemora, em 2014, 20 carnavais. O número é sugestivo. Foi em torno de um aumento de 20 centavos nas passagens de ônibus na cidade de São Paulo que teve início o longo processo de mobilização urbana que se espalhou pelo país. O samba feito pela ala de compositores para animar o desfile torna explícita essa referência. Estão presentes as questões pautadas nas mobilizações de junho. A palavra de ordem das manifestações foi: "Não é só pelos 20 centavos. É por direitos", os compositores recuperam essa afirmação e definem a rua como poesia e festa:

Não é só pelos 20 carnavais / Que vou pra rua comemorar / Nosso bloco faz a festa / Hoje rua é poesia é meu lugar / Vou de cara limpa ou mascarado / Tô no maior cartaz...

Há nessa leitura, ecos dos argumentos favoráveis à rua elencados por Henry Lefebvre (2008) em sua discussão sobre o fenômeno urbano. Na sua argumentação sobre o direito à cidade, Lefebvre (1991) considera a rua lugar de encontros, lugar em que se realiza o movimento, a mistura que caracteriza a vida urba- 
na. Sem esses elementos, enfatiza o autor, só pode existir separação, "segregação estipulada e imobilizada"; a rua, lugar de movimento e de mistura, permite o desenvolvimento de três funções essenciais: simbólicas, informativas e lúdicas, logo, "nela joga-se, nela aprende-se" a ser cidadão.

Ao mesmo tempo a rua é lugar de "convergência das comunicações e das informações, o urbano se torna aquilo que ele sempre foi: lugar do desejo, desequilíbrio permanente, sede da dissolução das normalidades e coações, momento do lúdico e do imprevisível" (LefEBVRE, 1991, p. 79). Momento do lúdico e do imprevisível que faz da ocupação das ruas a atividade preferida de um número cada vez maior de cidadãos que - como é possível observar contemporaneamente -, ao descobrir os blocos, seus circuitos e trajetos, descobrem, no mesmo movimento, a cidade. Para Lefebvre (2008, p. 27), o urbano é um espaço-tempo da "fruição, da superação da vida cotidiana alienada", que deve ser realizado pelo exercício do direito à cidade que é, segundo o autor, uma forma superior dos direitos: "direito à liberdade, à individualização na sociedade, ao habitat e ao habitar. $\mathrm{O}$ direito à obra (à atividade participante) e o direito à apropriação (bem distinto do direito de propriedade) estão implicados no direito à cidade" - aqui a ênfase recai no valor de uso e do gozo emancipatório da cidade e da festa. A ideia da cidade como obra, como valor de uso, como apropriação remete à questão da universalização dos acessos aos serviços públicos, moradia, transporte, lazer e cultura, enfim, à questão do direito à cidade que, colocada embrionariamente no período do carnaval, foi posta com veemência no espaço público pelos movimentos de junho de 2013.

A temática do direito à cidade tinha aparecido nas narrativas carnavalescas dos anos anteriores antecipando a agenda que se tornará hegemônica a partir de junho de 2013. Encontramos uma referência direta à primavera árabe e às diversas ocupações que vêm sendo realizadas, desde setembro de 2011, nos dois sambas que o mesmo bloco levou para o desfile em 2012:

É verão a primavera tá rua / É tudo nosso vamos ocupar / Zona do Euro tá rodando a bolsinha / E o Obama abriu pra gente a portinha / O melhor tá aqui no Leme / Eu é que não vou pra lá / Só não mando o Cabral / Ninguém sabe onde ele está.

A Zona do Euro refere-se à união monetária dentro da União Europeia e à adoção por alguns Estados do euro como moeda comum; na narrativa carnavalesca o substantivo zona designa, na linguagem informal, lugar de prostituição, de confusão, de tumulto. Ao mesmo tempo em que a questão global se faz presente, a problemática local comparece na crítica ao governador do estado que será alvo privilegiado conforme argumentamos. Um segundo samba faz referência às 
políticas públicas que gestaram o programa das Unidades de Polícia Pacificadora (UPP), implementadas na cidade a partir de 2010. Iniciativa que tem por objetivo a ocupação, pelo poder público e pelas forças de segurança, das favelas cariocas controladas por grupos criminosos. ${ }^{16}$ Faz referência, além disso, à ocupação da praça pública iniciada pelo movimento 15M em Madri, Espanha, como sugerem os dois primeiros versos do samba "La Ocupación", assim mesmo, em espanhol:

Preparei la ocupación / Vamú invadir em bloco esse lugar / Sou maior mas sem juízo / Levo a sério o que brinco é Carnaval! / (...) se o mundo anda sem rumo / Deixo a batucada me levar.

Os sambas agradaram os artistas de rua que participam do desfile apresentando uma performance em pernas de pau. É uma narrativa imagética. Cremos que não há desperdício em colocar, na íntegra, o e-mail enviado por esses artistas aos organizadores do bloco:

Mas vou Ihe adiantando por aqui, porque talvez seja mais fácil de explicar. A respeito das fantasias/figurinos dos pernaltas. Estava matutando para fazer uma fantasia legal e que ela dissesse alguma coisa às pessoas sobre o momento em que vivemos, fui dar uma olhada no samba para o figurino não ficar muito desconexo, e batata! Lá estava a referência à Primavera Árabe e a Ocupy Wall Street. Amei!!! Era o gancho que eu precisava. Então bolei uma roupa altamente atual e moderna. Seria a casa revolução no carnaval carioca. A dama vestida com uma barraca de camping como saia e uma sombrinha com bandeiras dos países, grávida. E o cavalheiro vestido de cartola e terno preto com a máscara do $\mathrm{V}$, que é o símbolo do Anonymus, os hackerativistas que andam paralisando os bancos.

Essa fantasia vai ser um estouro! No decorrer do bloco simularemos um parto, [do qual] que nascerá um planeta (um globo terrestre seria a barriga e nasceria), dando vida à frase de Eduardo Galeano: "Esse mundo de merda está prestes a parir um novo mundo!" O que estamos passando é dor desse parto. Tenho um bandeira do Brasil que poderíamos carregar também em uma determinada hora... e ao final do desfile, tiraremos a fantasia e ficaremos de preto, tiraremos a máscara, e por debaixo desta, estaremos com os olhos pintados de vermelho, e na camisa escrito: "Salve Xingú!", "Salve Pinheirinhos!".

Observamos que irreverência combina com consciência de cidadania e que o carnaval como festa é capaz de comentar o cotidiano e as questões prementes de forma ao mesmo tempo séria e criativa. 


\section{A CAMINHO DA DISPERSÃO}

De alguma maneira as narrativas produzidas para o carnaval de rua tanto quanto por essas manifestações abrem um espaço de diálogo entre o poder hegemônico e a população, como argumenta Ferreira (2012, p. 162-163):

A utilização de recursos carnavalizantes tais como o deboche, a invenção ou a caricatura (Bakhtin, 1987) são formas das expressões que estabelecem este diálogo. Se por um lado tais significações populares questionam ou mesmo abalam o poder constituído, por outro reiteram a força desse poder num processo de múltiplos sentidos. Deste modo, a simples existência de uma "força carnavalizante" não irá, necessariamente, gerar desestabilização ou alternância de poder. Neste sentido, o carnaval se apresenta como um espaço/ tempo de intensificação de diálogos geradores de narrativas carnavalizadas do mundo, capazes de explicar, exemplificar e esclarecer questões da sociedade que o engendra.

Nesse sentido podemos localizar a mais recente proposta que ocupa um lugar peculiar nas redes sociais. Trata-se da criação do bloco Ocupa Carnaval. Os responsáveis argumentam na página aberta em fevereiro de 2014 no Facebook tratar-se de um espaço de articulação política em que blocos de carnaval, grupos de arte, "coletivos de cultura, mídia ativistas, movimentos sociais e militantes independentes se organizam em conjunto". ${ }^{17}$ Nas reuniões semanais organizadas na Praça São Salvador - espaço que constituí hoje marco simbólico do carnaval de rua - os foliões militantes se ocupam na criação de paródias de marchinhas carnavalescas que têm, como alvo privilegiado as autoridades municipais e estaduais. Em função disso, marcaram seu desfile para a sexta-feira, véspera da data tradicional do início dos festejos momescos. Definiram um local de desfile: a proximidade da casa do governador. Definiram sua identidade, em função da saída do governador do estado do governo: é a Cabraleata - cortejo circense e fúnebre em celebração à saída do governador. O bloco Ocupa Carnaval apresenta sua carta de princípios:

O carnaval é o mais belo grito do povo! Ocupamos as ruas com estandartes, confetes e serpentinas mostrando que o Rio é nosso: suas colombinas e pierrôs estão vivos e pulsam. Abaixo as catracas que transformam a cidade em um grande negócio, onde o lucro prevalece sobre a vida, onde o dinheiro é mais livre que as pessoas. Enquanto capitalizarem a realidade, nós socializaremos o sonho. Viva a energia da rebeldia. Viva a criatividade das fantasias. Viva o Zé-Pereira e o Saci-Pererê. A cidade não está à venda e nos- 
sos direitos não são mercadoria. Foliões, uni-vos! Ocupa Eles. Ocupa Eu. Ocupa Tu. Ocupa Geral. Ocupa Carnaval. ${ }^{18}$

O poder de agendamento da mídia, conforme nos aponta a teoria Agenda Setting (WOLF, 2001), pauta tanto nossos temas de conversa quanto o grau de importância que temas e fatos devem ter na nossa compreensão da realidade. 0 discurso midiático hegemônico que privilegia os valores da funcionalidade e da objetividade racionalizante e plena de sentido é apropriado pelos sambas dos blocos que, sem escapar desse agendamento, ${ }^{19}$ tendem a revelar de forma desconcertante, mas também vivificante, os absurdos ou piadas contida nos próprios fatos, na própria história. Esse movimento é quase militante - não de alguma ideologia política, mas no sentido de desvelar o carnavalesco como constitutivo da própria existência. Isso ficou evidente, por exemplo, no samba que ganhou a disputa para o bloco Imprensa Que Eu Gamo no Carnaval de 2014. Os compositores após elencarem o conjunto de problemas e desmandos da política nacional, evocam o intérprete de Libras que marcou presença no funeral de Nelson Mandela como o único capaz de traduzir os descalabros da sociedade brasileira.

Baseado no tradutor do Mandela ${ }^{20}$ / Não autorizei a biografia / Fui espionado, tô Putim com Cia / Essa tal cura nem com médico cubano / Não me representa o Feliciano / Enterro de anão ainda é lenda / É quem nem o Amarildo, ninguém viu, ninguém viu... / Teve implante na cabeça do Calheiros / Ai que loucura, ai que badalo, Eike faliu / (...) Papa argentino habló, JMJ bombou / Baseado no Uruguai tá liberado / Aqui não pode topless e mascarado / E lá vem o tremsalão / Transportando uma cambada de ladrão / Eu não sei se vai ter copa / Mas é do copo que eu não abro mão / Rolezinho, Carnaval, cadê a Perimetral? / Black Bloc, isopozinho, o pózinho dos Perrela / Só explica esse zona o tradutor de Mandela.

Sem autorização, mas com livre acesso a toda a licença poética possível, os compositores de bloco são narradores essenciais já que, como afirma Fernando Resende (2011) corroborando a concepção de narrativa de Paul Ricoeur, "narramos porque é preciso, narramos para que haja vida".

\section{NOTAS}

1 Uma versão deste artigo foi apresentada no Confibercom, realizado na Universidade do Minho, Braga, Portugal, em abril de 2014.

2 Referenciados por Velloso (1986, p. 11), o caricaturista Raul Pederneiras define turuna como "chefe, valente, destemido" e Aurélio Buarque como "negro poderoso", valentão. 
3 Sobre as novas características das festas públicas na sociedade pós-industrial, ver, entre outros, Cavalcanti, 2013.

4 Sobre as Jornadas de Junho, ver Maricato et al., 2013.

5 http://www.ihu.unisinos.br/entrevistas/521910-monstro-e-multidao-aestetica-das-manifestacoes-entrevista-especial-com-barbara-szaniecki

6 http://www.ihu.unisinos.br/entrevistas/522986-os-escrachos-e-um-novofenomeno-de-participacao-social-entrevista-especial-com-ivana-bentes

7 Para uma problematização dessa questão, ver Queiroz, 1984.

8 https://www.facebook.com/photo.php?fbid=625746424140738\&set=gm.7301 $53837025241 \&$ type $=1 \&$ theater 0 debate sobre o direito a uso de máscaras fora do espaço carnavalesco está sendo convocado nas redes sociais e será mediado pelo presidente em exercício da OAB-RJ.

9 Samba de Noel Rosa feito em 1933. O Poeta da Vila foi homenageado pelo bloco Simpatia é Quase Amor no Carnaval de 2010, ano de seu centenário.

10 Mulheres de Zeca, bloco em homenagem a Zeca Pagodinho, idealizado pela cantora Dorina e fundado por Nilze Carvalho, Dayse do Banjo, Bia Aparecida, Lu Araujo, Tia Surica e a própria Dorina; nasceu de um bate-papo com as integrantes do Mulheres de Chico, que é só amor por Chico Buarque. "Elas me contaram que começaram indo pra frente da casa do Chico, e ficaram gritando o nome dele. Aí, pensei: por que não fazemos algo assim pelo Zeca também? Mas só que é mais para a mulherada de bar, de samba, de pé no chão, de rebolar..." diz Dorina para o jornal Extra.

11 http://www.info4.com.br/ver/ver.asp?Yw=MjE3NQ\&YQ=MjE3NQ\&bQ=MTc5 NzcyMTA\&bA=NzU4Ng\&Ym9vaw=MjA0NjY2MQ\&b3JkZW0=NjMwMjUzNjI\& who=77356

12 Artigo do compositor Moacyr Luz publicado no jornal O Dia, 17/01/2014.

13 Ver a esse respeito Cavalcanti, 2006, particularmente o capítulo 3.

14 Cf: http://oglobo.globo.com/blogs/prosa/posts/2011/08/06/o-passado-nofuturo-da-cidade-por-beatriz-jaguaribe-396853.asp

15 http://www.jb.com.br/rio/noticias/2012/10/18/fifa-desmente-cabral-eafirma-que-nao-pediu-demolicao-do-museu-do-indio/ consultado em 28/11/2013.

16 Sobre as Unidades de Polícia Pacificadora (UPP), ver Silva, 2012.

17 https://www.facebook.com/events/269581106531116/?fref=ts

18 https://www.facebook.com/events/269581106531116/?fref=ts

190 conjunto de manchetes dos meses que antecedem as escolhas de sambas de bloco de carnaval costumam ser os temas recorrentes, uma espécie de ideário, a partir do qual se tecem os versos e a realidade como metáfora.

20 https://www.youtube.com/watch?v=H-gOL-OWn_s 


\section{REFERÊNCIAS BIBLIOGRÁFICAS}

ALBUQUERQUE JÚNIOR, Durval Muniz. Festas para que te quero: por uma historiografia do festejar. Patrimônio e Memória. Unesp-FCLAs-Cedap, v.7, n.1, p.134-150, jun.2011.

BAKHTIN, Mikhail. A cultura popular na Idade Média e no Renascimento: o contexto de François Rabelais. São Paulo, HUCITEC-UNB, 1987.

CASCUDO, Luís da Câmara. Dicionário do folclore brasileiro. 2 ed. revista e aumentada, 2 v. Rio de Janeiro: Instituto Nacional do Livro/Ministério da Educação e Cultura, 1962.

CAVALCANTI, Bruno Cesar. Novos lugares da festa - tradições e mercados. Revista Observatório Itaú Cultural, São Paulo, n. 14, mai. 2013.

CAVALCANTI, Maria Laura Viveiro de Castro. O rito e o tempo: ensaios sobre o Carnaval. Rio de Janeiro: Civilização Brasileira, 1999.

Carnaval carioca: dos bastidores ao desfile. Rio de Janeiro: Editora UFRJ, 2006.

DAMATTA, Roberto. Carnavais, malandros e heróis: para uma sociologia do dilema brasileiro. Rio de Janeiro: Jorge Zahar Editor, 1981.

ESTEVÃO, Andréa; SAPIA, Jorge. Festas carnavalescas costurando e redesenhando a cidade. In: FACIN, Milton; NOGUEIRA, Maria Alice de; VAZ, Élida (Org.). Narrativas da cidade: perspectivas multidisciplinares sobre a urbe contemporânea. Rio de Janeiro: Editora E-Papers, 2013.

FERREIRA, Felipe. Inventando carnavais: o surgimento do carnaval carioca no século XIX e outras questões carnavalescas. Rio de Janeiro: Editora UFRJ, 2005.

FERREIRA, Felipe. Escritos carnavalescos. Rio de Janeiro: Aeroplano, 2012.

FORTUNA, Carlos; SILVA, Augusto Santos. A cidade do lado da cultura: espacialidades sociais e modalidades de intermediação cultural. In SANTOS, Boaventura de Sousa (org.). A globalização e as ciências sociais. 2.ed. São Paulo: Cortez, 2002.

HOBSBAWM, Eric. Nações e nacionalismos. Rio de Janeiro: Paz e Terra, 2004.

LEFEBVRE, Henri. A revolução urbana. Tradução Sérgio Martins. Belo Horizonte: Ed.UFMG, 2008, . O direito a cidade. Tradução Rubens Eduardo Frias. São Paulo: Editora Moraes, 1991.

LIMA, Fátima de Costa; FILLIPO, Bruno. Carnaval, um território de crise: as forças em debate no caso do Cristo mendigo (Beija-Flor, 1989). Textos Escolhidos de Cultura e Artes Populares. Rio de Janeiro, v.9, n.1, p. 121-142, 2012.

MARICATO, Ermínia et al. Cidades rebeldes: passe livre e as manifestações que tomaram as ruas do Brasil. São Paulo: Boitempo/Carta Maior, 2013.

MIGUES, Paulo. Carnaval baiano: as tramas da alegria e a teia de negócios. Dissertação (Mestrado) - Núcleo de Pós-graduação da Escola de Administração da Universidade Federal da Bahia, Salvador, 1996. 
NAVES, Santuza Cambraia. O violão azul: modernismo e música popular. Rio de Janeiro: Editora FGV, 1998.

ORTIZ, Renato. A moderna tradição brasileira. São Paulo: Ed. Brasiliense, 1989.

QUEIROZ, Maria Isaura Pereira de. A ordem carnavalesca. Tempo Social - Revista de Sociologia da USP, São Paulo, v.6, n.1-2, p. 27-45, 1994 (editado em jun. 1995).

RESENDE, Fernando. Às desordens e aos sentidos: a narrativa como problema de pesquisa. In: SILVA, Gislene et al. Jornalismo contemporâneo, impasses e perspectivas. Salvador: EDUFBA/Compós, 2011.

SANTOS, Milton. Por uma outra globalização. Rio de Janeiro: Ed. Record, 2004.

SENNETT, Richard. A corrosão do caráter: consequências pessoais do trabalho no novo capitalismo. Rio de Janeiro: Record, 2000.

SILVA, Jailson de Souza e. As unidades de polícia pacificadora e os novos desafios em relação as favelas cariocas. In: SILVA, Jailson de Souza e; BARBOSA, Jorge Luiz; FAUSTINI, Marcus (Org.). O novo carioca. Rio de Janeiro: Mórula Editora, 2012.

VELLOSO, Monica Pimenta. Modernismo no Rio de Janeiro: turunas e quixotes. Rio de Janeiro: Editora FGV, 1996.

. Que cara tem o Brasil? As maneiras de pensar e sentir o nosso país. Rio de Janeiro: Ediouro, 2000.

WOLF, Mauro. Teorias da comunicação. Lisboa: Editorial Presença, 2001.

Jorge Edgardo Sapia é cientista social pela UFF, mestre em sociologia pelo luperj e professor do Centro Universitário IBMR (Instituto Brasileiro de Medicina de Reabilitação) Laureate.

Andréa Almeida de Moura Estevão é jornalista, mestre em comunicação e cultura pela ECO/UFRJ, e professora da Unesa.

Recebido em: 06/05/2014

Aceito em: 15/07/2014 